\title{
MEMÓRIAS DA CONSTITUIÇÃO DO CENÁRIO ESPORTIVO AMADOR EM SANTA CATARINA
}

Recebido em: 18/11/2014

Aceito em: 22/05/2015

\author{
Camila da Cunha Nunes ${ }^{1}$ \\ Marcos Antônio Mattedi ${ }^{2}$
}

Universidade Regional de Blumenau - FURB

Blumenau - SC - Brasil

RESUMO: A constituição do cenário esportivo de Santa Catarina está relacionada com o processo de ocupação e desenvolvimento da região. No final do século XIX, muitas sociedades de tradição alemã foram fundadas no estado. As sociedades estavam relacionadas com os colonizadores europeus, que se estabeleceram e constituíram redes sociais. No início, foram desenvolvidos esportes como o tiro e a ginástica. Posteriormente, com o apoio das sociedades, há um período de transição no esporte do estado. É criada uma competição de esporte amador - os Jogos Abertos de Santa Catarina - que engloba várias modalidades esportivas, todas disputadas ao mesmo tempo. A partir desse marco na esfera esportiva, o esporte amador em Santa Catarina reestruturar-se. Desse modo, o objetivo do presente estudo é refletir sobre a constituição do cenário esportivo amador em Santa Catarina. Para tanto, realizamos uma pesquisa bibliográfica e documental.

PALAVRAS CHAVE: Esportes. Sociedades. Atividades de Lazer.

\section{MEMORIES OF THE CONSTITUTION OF THE AMATEUR SPORTING SCENE IN SANTA CATARINA}

ABSTRACT: The constitution of the sports scene of Santa Catarina is related to the process of occupation and development of the region. In the late nineteenth century, many societies of German tradition were founded in the state. The societies were related to the European settlers, who settled and formed social networks. At the beginning, sports like shooting and gymnastics were developed. Later, with the support of societies, there is a transition period in the sport in the state. A contest of amateur sport is created - the Open Games of Santa Catarina - which encompasses several sports, all played at the same time. From this milestone in the sports sphere, the amateur sport in Santa Catarina restructure itself. Thus, the objective of this study is to discuss the

\footnotetext{
${ }^{1}$ Mestre em Educação pela Universidade Regional de Blumenau - FURB e Mestre em Desenvolvimento Regional pela mesma instituição. Doutoranda no Programa strictu sensu em Desenvolvimento Regional da FURB. Professora do Centro Universitário de Brusque - UNIFEBE.

${ }^{2}$ Doutor em Ciências Sociais pela Universidade Estadual de Campinas - UNICAMP. Professor do Programa de Pós-graduação em Desenvolvimento Regional da Universidade Regional de Blumenau FURB.
} 
constitution of the amateur sports scene in Santa Catarina. Thus, we performed a bibliographic and documentary research.

KEYWORDS: Sports. Societies. Leisure Activities.

\section{Introdução}

Recorrer às memórias do esporte requer a procura dos fragmentos e vestígios do passado, presente e vislumbrar o futuro por meio dos seus enlaces. Mais precisamente, construir uma lógica permeada por indagações, escolhas, rupturas e intenções. Neste ínterim, o esporte como hoje o visualizamos composto por organizações esportivas, regras e um corpo técnico foi idealizado na Inglaterra. A sua essência e sistematização estabelece-se a partir das public schools (MELO, 2007). Desde então, sua prática se desenvolve em diversas instâncias mediado por interesses relacionados à saúde, sociabilidade, entretenimento, e até mesmo, fortalecimento da raça. Por outro lado, o esporte moderno está relacionado ao rendimento, a conquista de resultados e a quebra de recordes. $\mathrm{O}$ esporte de rendimento está vinculado a ideia de esporte amador (nãoprofissional) e profissional.

O esporte profissional se caracteriza quando o atleta que o desenvolve possui um contrato formal de trabalho com a instituição que representa. Já no esporte amador há a inexistência do contrato formal de trabalho (BRASIL,1998). O esporte amador tem estreita relação com a institucionalização do esporte através dos Jogos Olímpicos. A filosofia do amadorismo era requisito para a disputa da competição e imperou nos Jogos Olímpicos até 1984. Ainda se tratando da institucionalização do esporte, para os britânicos, somente poderia praticar esporte aquele que o pratica-se durante o tempo ócio e de forma desinteressada (RÚBIO, 2001). O recebimento de pagamento poderia 
corromper a sua pureza. O esporte deveria ser disputado por puro amor ao jogo. Os atletas não poderiam receber pagamento ou realizar qualquer tipo de propaganda visando obter lucro (AFIF, 2000).

No estado de Santa Catarina o esporte amador se institui mediado pelo processo de colonização. Deste modo, para compreender o contexto socioesportivo de Santa Catarina é preciso responder as seguintes questões: onde se praticava esporte em Santa Catarina? Como se praticava? Quais eram as modalidades praticadas? Quem eram os atletas? Até chegar a realização da $1^{\mathrm{a}}$ edição da competição de maior impacto no território catarinense, os Jogos Abertos de Santa Catarina - JASC. Para tanto, é necessário recorrer ao contexto histórico de Santa Catarina aproximadamente nos anos de 1850. Desse modo, o objetivo do presente estudo é refletir sobre a constituição do cenário esportivo amador em Santa Catarina. Para tanto, realizamos uma pesquisa bibliográfica e documental.

Em Santa Catarina o esporte amador se instituiu desde o seu processo de ocupação e desenvolvimento permeado, sobretudo por imigrantes europeus de origem alemã $^{3}$. Isso porque as manifestações esportivas estão relacionadas à vinda dos imigrantes que trouxeram sua tradição, sua cultura e seus costumes. Por sua vez, esse processo desencadeou formas de organização social em que o esporte se disseminou. A partir disso, se instauraram diversas formas de difusão do esporte no que concerne ao esporte amador como meio de socialização e posteriormente rendimento. Inicialmente percebemos a sistematização do esporte nas Sociedades de Ginástica e Sociedades de Tiro. As Sociedades de Tiro e as Sociedades de Ginástica são aglomerações próprias da

\footnotetext{
${ }^{3}$ Embora o processo de desenvolvimento e ocupação do Estado de Santa Catarina tenha sido realizado também por imigrantes de outras nacionalidades foram os alemães que instituíram as Sociedades de Tiro e as Sociedades de Ginástica onde realizavam-se as práticas esportivas.
} 
cultura alemã. As Sociedades de Tiro tal como os colonizadores alemães trouxeram para o Brasil, tiveram origem no século XIX (NOTÍCIAS DE VICENTE SÓ, 2012).

Além da realização de práticas esportivas, nesses espaços realizavam-se as competições esportivas. Assim, por meio das Sociedades mantinham-se as tradições alemãs em terras distantes com um caráter de socialização. As festas realizadas nas Sociedades representavam locais de interação com outras Sociedades de outros municípios. Por via das competições de tiro, havia as disputas para a escolha do melhor atirador. Dessa forma, as Sociedades representam um dos meios de propagação do esporte catarinense. Juntamente com as Sociedades de Tiro e as Sociedades de Ginástica surgem outras Sociedades com outros intuitos. Como também, as próprias Sociedades fragmentam-se no decorrer de sua institucionalização e perdem o seu significado inicial. Ao mesmo tempo em que, com o passar dos anos, o esporte se propaga, criam-se outras instituições esportivas e outros eventos esportivos mais expansionistas.

O processo de ocupação e desenvolvimento de Santa Catarina pode ser dividido em três momentos. (1) A ocupação do litoral catarinense realizada pelos vicentistas e açorianos. (2) No interior do Estado o caminho dos tropeiros. Caminho que ligava o Rio Grande do Sul a São Paulo para a compra e venda de carne e couro na região de Minas Gerais. (3) A colonização realizada as margens do Rio Itajaí-Açu e Itajaí-Mirim pelos europeus (MAAR, PERON, DEL PRÁ NETTO, 2011). Mais precisamente, os imigrantes alemães ocuparam o Planalto Norte e o Vale do Itajaí (COSTA, 2011). Ao estabelecerem pequenas aglomerações denominadas de Colônias, criaram diferentes formas associativas através das Sociedades.

O processo de imigração possibilitou a introdução, transformação e ao mesmo tempo a manutenção dos costumes próprios dos imigrantes alemães nas Colônias no 
Brasil. Na Alemanha era comum o associativismo estabelecido por meio das Sociedades. No contexto brasileiro, as Sociedades funcionavam como espaços de manutenção de uma identidade culturalmente marcada pela germanidade e sua reconfiguração na nova pátria (SEYFERTH, 2004). Possuíam a função de controlar os lazeres através de mecanismos de organização interna, que também refletiam fora do espaço associativo. Era o local onde se organizavam os festejos, competições, reuniões para tratar de assuntos da comunidade, manutenção de suas origens e impedir atividades consideradas promíscuas (FERREIRA; ABREU, 2005).

O associativismo é utilizado como uma ferramenta para integração e ao mesmo tempo de estruturação do tempo livre, "[...] tempo de lazer e de distração, por sua vez previsto, organizado, cheio, agitado, baseado em novos valores" (CORBIN, 2001, p. 6). Surge como uma possibilidade de escolha e distração para o preenchimento do tempo livre. O que ocasiona a formação de grupos que participam das atividades promovidas no interior das Sociedades. Sendo assim, constituíram-se através de uma dinâmica social. Nas Sociedades concentravam-se várias atividades, como festas de aniversário, casamentos, bailes, competições de tiro ao alvo, colação, dentre outras. Essas atividades possibilitaram o estabelecimento de Sociedades de diversas ordens, desde aquelas designadas à proteção dos imigrantes, culturais, sociais, até propriamente as desportivas e recreativas. As desportivas e recreativas propiciaram o desenvolvimento do esporte (FERREIRA; ABREU, 2005).

O desenvolvimento do esporte em quase todas as Colônias está relacionado ao estabelecimento de redes sociais. Uma forma de disseminação e manutenção do nacionalismo como forma de controle cultural. Assim, por um lado, está relacionado à expressão cultural da identidade étnica. Por outro, ao pensamento educacional da época, 
que considera a educação do corpo também através de exercícios físicos, como meio de preservação e manutenção da saúde, assim como de civilidade. Portanto, a prática de exercícios físicos expande-se mediada pelo estabelecimento de valores morais, desenvolvimento das capacidades físicas e sua contribuição para a nação (SOARES, 2009). Instituídos pelos alemães, os exercícios físicos se desenvolveram, inicialmente, nas Sociedades de Ginástica e nas Sociedades de Atiradores.

Em um contexto geral, em estudo realizado por Costa (1971), nos anos anteriores a 1900, a região Sul do Brasil comportava mais da metade do total de Associações Desportivas existentes no país. Ainda no período de 1960 a 1969, o número de Associações desportivas existentes na região Sul é quase o dobro da região Sudeste. No entanto, no que concerne ao estado de Santa Catarina no período de 1931 a 1960 é o momento em que o estado comporta o maior número de Associações desportivas, totalizando 238. De 1961 a 1969 há uma baixa neste número somando-se 125 Associações (COSTA, 1971). Tendo em vista a relação das Associações com a cultura pressupomos que estes números resultam da influência dos colonizadores alemães. Nesse processo o esporte foi se estruturando entre divergências e modificações mediado por atos políticos e históricos.

Além das Sociedades particularmente esportivas, desenvolveram-se Sociedades de diversas ordens, que demarcam a influência da colonização europeia na região. As Sociedades surgem, em Santa Catarina, através da fundação das Colônias. Dentre estas fundações, em algumas destas desenvolveu-se com maior ênfase o esporte que acarretou em regiões esportivas. A primeira Colônia foi fundada em 1829, denominada Colônia São Pedro de Alcântara, localizada próxima ao atual município de Florianópolis. Posteriormente vieram outras agremiações como a Colônia Blumenau em 1850, hoje, 
município de Blumenau; a Colônia Dona Francisca em 1851, hoje, município de Joinville; e, em 1860, onde se localiza o município de Brusque, a Colônia ItajaíBrusque.

Neste movimento de colonização, algumas modalidades esportivas de origem germânica foram desenvolvidas. Na região Sul e parte do Sudeste do Brasil, algumas manifestações corporais se expandem e enraízam subsidiadas pelos alemães. Inicialmente desenvolveram-se a ginástica e o tiro, estas práticas desencadeiam o aparecimento de outras manifestações corporais e propriamente alguns esportes. A ginástica de origem alemã, os jogos de punhobol, o bolão, a bocha e mais tarde, já no século XX, esportes como futebol e o handebol são alguns exemplos (SOARES, 2009). O desenvolvimento destas práticas está relacionado às Sociedades de Ginástica e as Sociedades de Atiradores um meio de aglomeração social. A sistematização do esporte pelas Sociedades resulta mais tarde em 1960, no fortalecimento do Sistema Esportivo Catarinense mediado pela criação dos Jogos Abertos de Santa Catarina (JASC).

Contrário à ênfase de competição e rendimento que se estabelece o esporte moderno, as manifestações esportivas desenvolvidas no interior das Sociedades tinham o caráter de entretenimento, preservação da sua origem e sociabilidade. As Sociedades eram um meio de aglomeração cultural. Com o decorrer dos anos e a realização de competições esportivas, foi inserido no interior das Sociedades o esporte moderno, com suas devidas características. As Sociedades suprem a demanda de atletas necessários para as Fundações Municipais de Esportes (FMEs), ou órgãos e entidades de administração do esporte municipal ${ }^{4}$, disputarem as competições promovidas pelo

\footnotetext{
${ }^{4}$ Desde que devidamente inscritos na FESPORTE, apresentando a lei, documento que os constituiu ou declaração assinada pelo Prefeito do município. Ou ainda, entidades esportivas, credenciadas pelo Chefe do Poder Executivo municipal para tal fim (FESPORTE, 2014b). Essas são as entidades que podem participar dos eventos promovidos pela FESPORTE.
} 
Estado e ao mesmo tempo suas instalações esportivas são utilizadas para a promoção de eventos. O esporte disseminou-se principalmente através das Sociedades de Ginástica e das Sociedades de Tiro.

\section{A Formação do Cenário Esportivo Amador Catarinense}

Em Joinville no ano de 1858, Blumenau em 1873 e em São Bento do Sul em 1925, são criadas as primeiras Sociedades alemãs de ginástica (SOARES, 2009). A ginástica está diretamente relacionada ao contexto alemão. Os alemães são considerados os precursores dessa modalidade esportiva através do seu idealizador Friederich Ludwig Jahn. Idealizador da ginástica patriótica com fim político nacionalista, sendo “construída a partir das 'bases científicas', ou seja, das ciências que dominavam a sociedade da época: a biologia, fisiologia e a anatomia" (SOARES, 1994, p. 66). Também desenvolveu "obstáculos artificiais", como a barra fixa e as paralelas, que posteriormente são denominados aparelhos próprios da ginástica olímpica. Ainda, houve outros idealizadores da ginástica alemã como Cristoph Friederich Guts Muths e Adolph Spiess (SOARES, 1994).

Em Joinville, foi fundada em 1858 a Deutscher Turverein zu Joinville (Sociedade Ginástica de Joinville). A ginástica de caráter utilitarista apresentava-se como o único meio de recreação na Colônia. Eram utilizados alguns materiais, “obstáculos artificiais”, para a prática dos exercícios como: barras fixas, paralelas, trampolim, cavalete para trapézio, cabo e mastro para transpor. Todos os meninos da Colônia, pelo menos duas vezes na semana no período noturno, praticavam ginástica. Esses, por vezes chamados de ginastas, caracterizavam os atletas que representavam as 
Sociedades/Associações/Clubes ${ }^{5}$ nas competições esportivas. Em 1908, foi realizada a festa do Cinquentenário de fundação da Sociedade Ginástica de Joinville e, concomitantemente, competições esportivas de barra fixa; paralelas; cavalo; salto em distância e salto em altura. Posteriormente, desenvolveram-se competições de atletismo, basquete, ginástica, voleibol, punhobol e bolão (SOCIEDADE GINÁSTICA DE JOINVILLE, 1958).

Em Blumenau, em 1873, funda-se a Turnverein Blumenau (Sociedade Ginástica Blumenau). Nessa Sociedade, além da ginástica, também desenvolveram-se outros esportes como o preaball, faustball (punhobol) e o handball (handebol). A Sociedade não tinha sede própria, utilizava-se da sede da Sociedade de Atiradores. Essa Sociedade de Ginástica é considerada o local que deu origem a estrutura organizacional esportiva de Blumenau, que se sustenta até os dias de hoje (SOARES, 2009). Na mesma linha de fundamentação, em 1925 funda-se na cidade de São Bento do Sul a Sociedade Ginástica e Desportiva São Bento (OLIVEIRA NETO, 2010). A prática da ginástica nesse período histórico é compreendida tanto como uma prática disciplinar e utilitária como um lazer.

Outra forma de associativismo esportivo desenvolvido em Santa Catarina é estabelecida pelos Schutzenverein (Sociedade de Atiradores). Nesse tipo de Sociedade também se constituíram as bases esportivas. Em Blumenau, no ano de 1859, funda-se o primeiro Schutzenverein Blumenau, atualmente Tabajara Tênis Clube, onde se realizava a manifestação esportiva do tiro. No sentido de manter seus costumes e aspectos culturais, anualmente se realizava a Schutzenfest (festa dos atiradores). Na festividade,

\footnotetext{
${ }^{5}$ Em decorrência de momentos históricos de repressão em alguns períodos se verifica o fechamento e a alteração da nomenclatura das Sociedades. Diante disso, utilizamos como sinônimo de Sociedades no decorrer do texto os termos: Associações e Clubes. Os momentos de repressão foram promovidos pela $1^{\text {a }}$ Guerra Mundial, $2^{\mathrm{a}}$ Guerra Mundial e a Campanha de Nacionalização ocorrida no Brasil.
} 
era nomeado o Rei dos Atiradores. O título era concedido ao atirador que tivesse maior destreza e habilidade no tiro. Isso rendia ao ganhador grande prestígio social. No início eram realizadas as festas, sobretudo no meio rural e com o tempo se transformaram em festas populares nas Colônias (SOARES, 1989).

As competições se estabeleciam também em momentos distintos à Schutzenfest. Eram realizadas competições internas e intermunicipais, como: Concursos de Rei do Tiro, Rei do Pássaro, Rei de Honra, Rei do Dia e Troféu. Também se observava a participação feminina nas competições de Rainha do Tiro. Os sócios das Sociedades de Tiro eram sujeitos à contribuição anual para a Federação Catarinense. Além da contribuição para a manutenção das Sociedades que eram mantidas pelos seus sócios (SOARES, 1989). Com o decorrer do tempo, os valores foram aumentando e consequentemente elitizando os seus participantes. Os frequentadores dos Schutzenverein eram a elite local composta por liberais, mecânicos, administrativos, agricultores, comerciantes e por indivíduos que não se localizou o grupo profissional (PETRY, 1982). No Quadro ilustrativo abaixo observamos no período de 1859 -1863 a profissão dos associados participantes do Schutzenverein Blumenau:

Quadro 1. Schützenverein de Blumenau: profissões dos sócios, admissões e desistências $(1859-1863)$.

\begin{tabular}{|c|c|c|c|c|c|c|c|c|c|c|c|c|}
\hline \multirow{2}{*}{$\begin{array}{c}\text { Grupo } \\
\text { Profissional }\end{array}$} & \multicolumn{2}{|c|}{1859} & \multicolumn{2}{|c|}{1860} & \multicolumn{2}{|c|}{1861} & \multicolumn{2}{|c|}{1862} & \multicolumn{2}{|c|}{1863} & \multicolumn{2}{|c|}{ Total } \\
\hline & Adm. & Des. & Adm. & Des. & Adm. & Des. & $\begin{array}{l}\text { Ad } \\
\text { m. }\end{array}$ & Des. & Adm & Des. & Adm. & Des. \\
\hline Liberais & 5 & - & - & 1 & 1 & - & 2 & - & - & 2 & 8 & 3 \\
\hline Mecânicos & 6 & - & 2 & - & 5 & 1 & - & 1 & 10 & 2 & 23 & 4 \\
\hline Administrativos & 10 & - & 2 & 1 & 2 & - & 2 & 1 & 1 & - & 17 & 2 \\
\hline Agricultores & 23 & - & 3 & 3 & 5 & 1 & 11 & 2 & 24 & 10 & 66 & 16 \\
\hline Comerciantes & 8 & - & 1 & 1 & 3 & 1 & 1 & - & 1 & 1 & 14 & 3 \\
\hline Não localizados & 2 & - & - & - & - & - & - & 1 & 8 & 3 & 10 & 4 \\
\hline Totais & 54 & - & 8 & 6 & 16 & 3 & 16 & 5 & 44 & 18 & 138 & 32 \\
\hline
\end{tabular}

Fonte: Adaptado de Petry (1982, p. 42). 
Os grupos profissionais são constituídos pelos liberais que são advogados, médicos, professores e clérigos; mecânico que compreende serralheiros, torneiros, oleiros, charuteiros e marceneiros; administrativos, pessoas que trabalhavam junto ao diretor da Colônia como guarda-livros, agrimensores e juiz de paz; agricultores, aqueles que se dedicavam exclusivamente à lavoura; comerciantes que são os farmacêuticos, açougueiros, vendeiros, hoteleiros e ourives ${ }^{6}$. O maior número de sócios eram agricultores, tendo em vista as características da própria Colônia Blumenau. Observa-se no quadro 1 que, no período de 1860-1861, houve um número de admissões e desistências equilibrado em todas as profissões. No período de 1862-1863, houve um aumento expressivo de sócios agricultores. Entretanto, o ano de 1863 também se caracterizou por um grande número de desistências dos agricultores (PETRY, 1982).

Com aumento do número de habitantes, decorrente do aumento do número de imigrantes, a quantidade de Schutzenverein também aumentou. No período de 1859 1912 somavam-se vinte sociedades distribuídas pela Colônia Blumenau, como indica o (QUADRO 2). No período de 1850 - 1880, o ano de 1868 foi o de maior crescimento de imigrantes alemães, totalizado em 1686 imigrantes sendo que eles se fixavam ao longo das margens do Rio Itajaí-Açu e seus afluentes. Até o período de 1870 observamos somente a manifestação esportiva do tiro nas competições desenvolvidas na Schutzenfest, "tiro ao alvo" e "tiro ao pássaro". Em 1870, foi construída uma cancha de bolão. Em 1873, com a fundação da Sociedade de Ginástica Blumenau, o leque de modalidades aumentou para ginástica olímpica, atletismo, natação e jogos esportivos, principalmente o punhobol (PETRY, 1982).

\footnotetext{
${ }^{6}$ Ourives são indivíduos que fabricam ou vendem objetos de ouro.
} 
Quadro 2. Schützenverein de Blumenau (1859 - 1912).

\begin{tabular}{|l|c|c|}
\hline Ano & Local & Denominação de origem \\
\hline 1859 & Sede & Schützenverein Blumenau \\
\hline 1875 & Indaial & Schützenverein Indaial \\
\hline 1877 & Itoupava & Schützenverein Ribeirão Itoupava \\
\hline 1879 & Warnow & Schützenverein Warnow \\
\hline 1880 & Garcia & Schützenverein Garcia Jordan \\
\hline 1893 & Itoupava & Verein Gesellger Teutonia \\
\hline 1894 & Fidélis & Verein Gemüthlichkeit \\
\hline 1895 & Passo Manso & Schützenverein Passo Manso \\
\hline 1896 & Vila Itoupava & Schützenverein Harmonie \\
\hline 1898 & Itoupava Rega & Schützenverein Itoupava Rega \\
\hline 1899 & Itoupava & Schützenverein Eintracht \\
\hline 1900 & Velha Central & Schützenverein Velha Central \\
\hline 1907 & Itoupavazinha & Schützenverein Itoupavazinha \\
\hline 1910 & Harmonie & Schützenverein Harmonie \\
\hline 1911 & Indaial & Schützenverein Polakia \\
\hline 1911 & Fortaleza & Schützenverein Fortaleza Alta \\
\hline 1912 & Belchior & Schützenverein Gemütlichkeit \\
\hline 1912 & Bela Aliança & Schützenverein Bella Alliança \\
\hline 1912 & Velha & Schützenverein Neue Velha \\
\hline
\end{tabular}

Fonte: Adaptado de Petry (1982, p. 86) e Soares (1989, p. 17).

As modalidades de remo e natação também já ganhavam espaço no município de Blumenau praticados no rio Itajaí-Açú. Em 1920, foi fundado o clube de remo denominado Clube de Regatas e no mesmo ano também o Clube Náutico América. A primeira regata realizada foi considerada intermunicipal, contando com a participação de Clubes do município de Itajaí. Outro Clube que ofereceu préstimos para o desenvolvimento foi o Clube Náutico Ipiranga (inicialmente chamado de Verein Gesellger Teutonia) incentivando o remo. A natação ganha força no município na década de 1950, com a disputa de travessias no Rio Itajaí-Acú. O punhobol é mais uma das modalidades praticadas que tem como base o Guarani Esporte Clube (antigo América Futebol Clube) (TRINDADE; PEIXER, 2013). 
Em Brusque (Colônia Itajaí-Brusque), foi fundado o primeiro Schutzenverein Brusque (Clube de Caça e Tiro "Araújo Brusque”) em 1866, tendo como atividade principal o tiro ao alvo e também se realizavam jogos de bolão e bocha (NOTÍCIAS DE VICENTE SÓ, 1985). Nessa Colônia era desenvolvida mais uma atividade caracterizada como corrida de cavalos (mais tarde essa prática estrutura-se e é conhecida como turfe), no esporte moderno compreende uma das modalidades do hipismo. A atividade era realizada na Rua do Schutzenverein (SEYFERTH, 1974). Em 1900 é fundado o Turnverein Brusque, que desenvolvia inicialmente a ginástica. A sua primeira sede contava também com uma cancha de bocha. Desenvolviam-se também as modalidades de basquete, handebol de campo, atletismo, voleibol e ginástica. Devido aos acontecimentos políticos, após a Segunda Guerra Mundial, a Sociedade passa a se chamar Sociedade Esportiva Bandeirante (BADO, 2000).

A Sociedade Esportiva Bandeirante foi fundada com a findalidade de dedicar-se ao esporte, conforme lavrado em sua ata de fundação. O esporte era praticado por seus sócios, geralmente no período noturno, após suas ocupações profissionais. Os sócios se reuniam para jogar bolão. Praticava-se ainda, algumas vezes, a ginástica sob a orientação do instrutor ${ }^{7}$ Jacob Frank. Em 1923, a Sociedade firma contrato com o Esporte Club Brusquense, atual Clube Atlético Carlos Renaux. Desse modo, passa a ser desenvolvido também o pé-bol (futebol). Nas festividades do $39^{\circ}$ Aniversário de Fundação observa-se a apresentação dos ginastas da Sociedade em vários exercícios de ginástica (barra e paralelas), jogo de handebol de campo contra a Sociedade Ipiranga de Blumenau e uma corrida (BADO, 2000). Essa Sociedade, em 1960, será palco dos JASC, segunda maior competição esportiva do país.

\footnotetext{
7 Anteriormente a criação dos cursos de graduação em Educação Física, os exercícios físicos eram ministrados pelos instrutores formados por instituições militares (COLETIVO DE AUTORES, 1993).
} 
Ainda antes da realização dos JASC, a Sociedade promoveu intensamente atividades esportivas e também mobilizou outras Sociedades através de competições e jogos. Caso que aconteceu com: Feminino Volley Clube, Clube Náutico Marcílio Dias, Estudantes de Blumenau, Clube Atlético Carlos Renaux, Equipe dos Oficiais e Sargentos de Itajaí, Associação Esportiva Caxias, Clube Esportivo Paysandú, Sociedade Ipiranga etc. Em 1960 um ato promovido na Sociedade Esportiva Bandeirante modifica o cenário esportivo catarinense (BADO, 2000). Literalmente, nas palavras de Bado (2000), observamos a importância que essa sociedade representa para o esporte catarinense ao criar uma competição que envolve diversas modalidades esportivas sendo disputadas ao mesmo tempo.

Os JASC foram vistos como movimento redentor do esporte amador catarinense, que sofria com a falta de auxílio governamental e com os longos campeonatos estaduais, que marcavam jogos entre equipes de cidades muito distantes entre si, fatores prejudiciais para o bom andamento dos certames de diversas modalidades (p.187).

Desterro, atual cidade de Florianópolis, também tem relação com as primeiras manifestações esportivas em Santa Catarina, desenvolvendo uma modalidade até então ainda não citada. Em 1861, através dos oficiais da Marinha de Guerra, é fundada a Sociedade de Regatas onde é desenvolvida a modalidade de remo. Já no primeiro ano, foi realizada a primeira regata com cinco páreos de escaleres e um de baleeiras. Os participantes foram aprendizes de marinheiros, profissionais, amadores e menores. Em 1863, é fundada a Sociedade Patriótica de Tiro demonstrando a forte influência dessa modalidade em várias regiões do estado de Santa Catarina. Em 1872, é fundado o Clube Doze de Agosto, onde passaram a serem praticadas diversas modalidades esportivas 
como o tiro ao alvo, tênis, bolão, natação e basquetebol (MAZO, 2005). Observou-se a prática do remo também em Sociedades Blumenauenses.

Além das Sociedades citadas, no estado de Santa Catarina, há outras distribuídas em diversas localidades, como: Taió, Pomerode, Corupá, Massaranduba, Shroeder, Jaraguá do Sul (SOARES, 1989) que também se instituem antes de 1960. Entretanto, nos restringimos às apresentadas devido à repetição das modalidades esportivas e, sobretudo, temos como foco os municípios de Brusque, Joinville, Blumenau e Florianópolis. Essa delimitação estabelecida somente aos quatro municípios devesse pelo fato de Brusque sediar a primeira edição dos JASC; e, por Joinville, Blumenau e Florianópolis serem os únicos municípios até o ano de 2013 a conquistarem o título de campeão geral dos JASC.

Outro ponto importante a ser ressaltado, ainda no que concerne às Sociedades, é a introdução de novas manifestações desportivas na década de 50. Além disso, a fundação de algumas Federações $^{8}$ estaduais, como por exemplo, a Federação Catarinense de Tiro ao Alvo em 1950. Isso acarretou novas dinâmicas de campeonatos, preparação e ocupação do ambiente associativo. Dessa forma, as Sociedades estabelecem outras relações permeadas pela institucionalização do esporte espetáculo (FERREIRA; ABREU, 2005).

Inicialmente, recorrendo à nomenclatura das Sociedades, desenvolveram-se no estado de Santa Catarina as modalidades esportivas de tiro; ginástica e; bolão, sobretudo durante as festividades promovidas pelas Schutzenfest. Mediado pelo processo de ocupação e desenvolvimento da região os municípios de Blumenau, Joinville e Florianópolis foram pioneiros no desenvolvimento do esporte junto as Sociedades.

\footnotetext{
${ }^{8}$ Federações são entidades regionais responsáveis por administrar determinada modalidade esportiva. As federações são filiadas a Confederação (entidade nacional) do respectivo esporte.
} 
Posteriormente, adentraram nessas instituições outras manifestações esportivas que permearam a institucionalização do esporte moderno e a consequente modificação dos seus objetivos. Com o desenvolvimento do esporte e a criação de eventos esportivos, algumas Sociedades se tornam marcantes tanto na criação como para a manutenção desses (JENICHEN, 1993). Entretanto, a configuração interna das Sociedades se modificou, antes se praticava esporte por lazer, agora, as práticas passam a serem sistematizadas visando também o êxito e a performance. Com esse advento, as Sociedades passam a possuir outros sentidos. Como por exemplo, o de promover a iniciação esportiva e sediar os eventos esportivos legitimados pelas instituições que se firmam no entorno do esporte. A Sociedade Esportiva Bandeirante é uma dessas instituições e será palco da $1^{a}$ edição dos JASC. Os JASC é uma invenção regional, inspirado nos Jogos Abertos do Interior de São Paulo (JAI).

\section{Os Jogos Abertos de Santa Catarina e sua Institucionalização}

O esporte moderno é um fenômeno social de grande visibilidade e possui forte poder de mobilização, sobretudo através dos grandes eventos esportivos. Já foram realizados alguns no Brasil - Jogos Pan-americanos (2007), Jogos Mundiais Militares (2011), Copa do Mundo de Futebol (2014) - iremos ainda visualizar isso em outros eventos esportivos que acontecerão no Brasil. Em 2014 a Copa do Mundo de Futebol abrangeu 12 cidades brasileiras. Dois anos depois, teremos as Olimpíadas no Rio de Janeiro. Esses eventos irão influenciar a mobilidade das diversas regiões brasileiras e demarcar um território esportivo. No contexto catarinense, os JASC é a competição esportiva amadora de maior magnitude. Movimenta vários setores antes, durante e após 
sua realização. É uma invenção regional, criado em 1960, anualmente se institucionaliza de diferentes formas por atores e contextos diversos.

A origem dos JASC funde-se com o desenvolvimento da Sociedade Esportiva Bandeirante. A ideia de fomentar a competição surgiu bem antes do seu desenvolvimento há exatamente 11 anos, em 1949. Surgiu devido a uma visita realizada pela delegação do Bandeirante às festividades do cinquentenário do Clube Pinheiros de São Paulo. Nessa ocasião, os membros da delegação ficaram a par dos detalhes do funcionamento dos JAI. Isso desencadeou entusiasmo e logo depois a ideia foi esquecida. Até que em 1957 a chama é acesa novamente, pois a equipe de voleibol feminino do Bandeirante participou dos JAI realizado em São Carlos. Esse êxito também consagrou a Sociedade no esporte nacional amador (BADO, 2000).

Os JAI tem o intuito de premiar o desenvolvimento da prática desportiva nos municípios do estado de São Paulo e contribuir para o aprimoramento técnico das 24 modalidades em disputa (SÃO PAULO, 2014). Teve sua gênese no ano de 1936, em Monte Alto, por meio da iniciativa de Horácio "Baby" Barone com o apoio do presidente da Associação Atlética Montealtense, Manoel de Carvalho Lima. A primeira edição dos JAI surge do primeiro Campeonato Aberto de Bola ao Cesto ${ }^{9}$ do Interior que reuniu atletas de uma única modalidade. Naquela época, era permitida a participação de municípios de outros estados. Com o passar dos anos, aumentou o número de modalidades disputadas e restringiu-se a participação aos municípios paulistas. Em 1939, a competição é oficializada e passa a ser organizada pelo estado de São Paulo e, atualmente, é organizada pela Secretaria do Esporte, Lazer e Turismo. Em 1959, é oficializado os Jogos Regionais como classificatório para os JAI. A partir disso, o

\footnotetext{
${ }^{9}$ Hoje conhecido como Basquete.
} 
estado foi dividido em 8 regiões e expandiu-se a competição (PENAFORT, 2001; BANDEIRA; RODRIGUES; NAVARRO, 2009).

Anteriormente à competição no estado de Santa Catarina, eram realizados ainda em outros estados. No Rio Grande do Sul, no período de 1954 a 1963, na cidade de Porto Alegre eram realizados os Jogos Abertos Femininos com o intuito de incentivar a prática esportiva das mulheres (GOELLNER et al., 2007). No Paraná, a competição começou a realizar-se em 1957 através da Liga de Esportes Amadores de Londrina (MEZZADRI, 2000; PARANÁ, 2014). A primeira versão catarinense da competição foi realizada em 1960. Começou a ser pensada a partir do interesse de Arthur Schlösser, considerado o "pai dos JASC", em 1956. Momento em que ele ficou encarregado da parte esportiva dos eventos que seriam realizados em comemoração ao Centenário de Fundação de Brusque. Em 1956, Schlösser tentou conseguir informações referente a realização dos JAI, mas não obteve sucesso (GOMES; FRITSCHE, 2010).

Considerando isso, a competição começou a ser projetada em 1957, quando uma delegação composta por vinte e oito pessoas da Sociedade Esportiva Bandeirante representou Santa Catarina nos JAI. A delegação foi custeada pelo empresário e atleta Arthur Schlösser. Além de participar da competição, o intuito principal era conseguir informações a respeito dos JAI. Rubens Facchini obteve êxito ao conseguir, em contato com a Comissão Central Organizadora (CCO), documentos que serviram de base para os JASC. Em 1958, é oficializada a primeira CCO dos JASC. Entre reuniões e projeções, em 1960 é realizado os JASC junto às festividades de comemoração do Centenário de Brusque por meio de Schlösser em parceria com colaboradores (GOMES; FRITSCHE, 2010). 
No decorrer de sua institucionalização os JASC alteram a estrutura esportiva no estado, inicialmente mantido pelos clubes. Tornou-se a competição de maior impacto esportivo catarinense. Durante a competição, a disputa é realizada entre os municípios catarinenses representados por meio das FMEs. Os JASC encontra-se na 54 edição, sendo que em duas ocasiões - 1983 e 2008 - foram canceladas devido à ocorrência de fenômenos naturais. No início, diversos eram os entraves devido à falta de infraestrutura das estradas catarinenses e a dificuldade de divulgação das informações. Durante seus anos de existência sua estrutura foi modificada e tornou-se complexa. Considerando esse processo, é possível estabelecermos três fases distintas de operacionalização: (1) pioneirismo; (2) consolidação; (3) expansão.

A primeira fase consiste no período que compreende sua institucionalização tendo a duração de 15 anos (1960-1975). Nesse período, os atletas participantes são cedidos pelos clubes para representar os municípios. Os jogos são organizados pela CCO supervisionada pelo conselho técnico. Em 1969, é criado o título de campeão geral $^{10}$ dos JASC que altera a ênfase dada à competição, tornando-o fonte de uso político, ocasionando maior investimento público (GOMES; FRITSCHE, 2010). Em 1970, é criada a Escola Superior de Educação Física e Desportos de Joinville e esta passa a oferecer material humano qualificado para a organização da competição. Além disso, a ampliação dos sistemas de ensino superior propicia expertises de diversas áreas

\footnotetext{
${ }^{10}$ Segundo o Regulamento Geral da competição no art. 72 a classificação final dos municípios será definida utilizando-se a soma de pontos obtidos na apuração por modalidade e naipe, a saber: $1^{\circ}$ Lugar 13 pontos; $2^{\circ}$ Lugar 8 pontos; $3^{\circ}$ Lugar 5 pontos; $4^{\circ}$ Lugar 3 pontos; $5^{\circ}$ Lugar 2 pontos; $6^{\circ}$ Lugar 1 ponto (FESPORTE, 2014b).
} 
que oferecem préstimos ao evento. Ainda nesse período a competição teve a ascendência de oito para dezenove modalidades disputadas (QUADRO 2) ${ }^{11}$.

A fase de consolidação (1976-1993) é instituída por marcos legais que determinam ações. Inicia-se pela homologação da Lei no 5.089 em 1975, que dispõe sobre a organização da Administração Estadual. O desporto e a Educação Física passam para o âmbito da Secretaria da Educação e Cultura do estado e é criado o Departamento de Educação Física e Desportos (DED) ${ }^{12}$. Mediado por esse ato, em 1976, a realização dos JASC passa a ser de responsabilidade do governo estadual. A partir disso, os JASC passa a ser organizado pelo DED (VIEIRA, 1983). Com isto, é reestruturada a competição e ampliada, criando-se as etapas regionais e, posteriormente, em 1983, as microrregionais (QUEIROZ, 1990). A fragmentação da competição em etapas teve o intuito de diminuir os municípios participantes na etapa estadual. Contribuindo para a descoberta de talentos, em 1981 a Educação Física torna-se disciplina obrigatória no ensino primário estadual. Em 1984, com o auxílio das tecnologias, foram utilizados pela primeira vez softwares para a realização das inscrições dos municípios (GOMES; FRITSCHE, 2010).

A fase de expansão que ocorre a partir de 1994, é marcada pela criação da FESPORTE. A FESPORTE tem a finalidade de projetar e executar a política de desportos do estado de Santa Catarina. Foi instituída por meio da legislação estadual, assegurada pela Lei $\mathrm{n}^{\circ}$ 9.131, de 1993. Está associada ao Sistema Desportivo Catarinense legitimado pela Lei $n^{\circ}$ 9.808, de 1994. O Sistema Desportivo Catarinense compreende a Secretaria de Cultura, Turismo e Esporte (SOL); a FESPORTE; o CED; o

\footnotetext{
11 A criação das Federações também oferece assistência aos JASC inicialmente chamada Liga Santa Catharina de Desportos Terrestres fundada em 1924. Com a homologação da Lei estadual nº 1.611 de 26 de setembro de 1928 é substituída pela Federação Catarinense de Desportos.

${ }^{12}$ Em 1977, o DED transforma-se em Unidade Operacional de Educação Física (UNED). Ainda neste mesmo ano cria-se a Secretaria de Cultura, Esporte e Turismo (VIEIRA, 1983).
} 
Tribunal de Justiça Desportiva (TJD); as entidades estaduais de administração e prática do desporto e as Federações Desportivas ou equivalentes e seus filiados (SANTA CATARINA, 1994). A FESPORTE é responsável pela realização de eventos esportivos promovidos pelo Governo do Estado. Entre os eventos, os JASC é o de maior repercussão esportiva em Santa Catarina.

Quadro 2. Modalidades esportivas nas fases dos JASC.

\begin{tabular}{|c|c|c|c|c|c|c|}
\hline \multirow{2}{*}{$\begin{array}{l}\text { Ano / } \\
\text { Modalidade } \\
\text { Atletismo masculino }\end{array}$} & \multicolumn{2}{|c|}{$\begin{array}{c}1960- \\
1975 \\
\text { Pioneirismo }\end{array}$} & \multicolumn{2}{|c|}{$\begin{array}{c}1976- \\
1993 \\
\text { Consolidação }\end{array}$} & \multicolumn{2}{|c|}{$\begin{array}{c}1994-2013 \\
\text { Expansão }\end{array}$} \\
\hline & $\mathrm{X}$ & $\mathrm{X}$ & $\mathrm{X}$ & $\mathrm{X}$ & $\mathrm{X}$ & $\mathrm{X}$ \\
\hline Atletismo feminino & $\mathrm{X}$ & $\mathrm{X}$ & $\mathrm{X}$ & $\mathrm{X}$ & $\mathrm{X}$ & $\mathrm{X}$ \\
\hline Basquete masculino & $\mathrm{X}$ & $\mathrm{X}$ & $\mathrm{X}$ & $\mathrm{X}$ & $\mathrm{X}$ & $\mathrm{X}$ \\
\hline Basquete feminino & - & - & - & $\mathrm{X}$ & $\mathrm{X}$ & $\mathrm{X}$ \\
\hline Bocha Rafa masculino & $\mathrm{X}$ & $\mathrm{X}$ & $\mathrm{X}$ & $\mathrm{X}$ & $\mathrm{X}$ & $\mathrm{X}$ \\
\hline Bocha Rafa feminino & - & - & - & $\mathrm{X}$ & $\mathrm{X}$ & $\mathrm{X}$ \\
\hline Bolão 16 masculino & - & - & - & $\mathrm{X}$ & $\mathrm{X}$ & $\mathrm{X}$ \\
\hline Bolão 16 feminino & - & - & - & $\mathrm{X}$ & $\mathrm{X}$ & $\mathrm{X}$ \\
\hline Bolão 23 masculino & - & $\mathrm{X}$ & $\mathrm{X}$ & $\mathrm{X}$ & $\mathrm{X}$ & $\mathrm{X}$ \\
\hline Bolão 23 feminino & - & $\mathrm{X}$ & $\mathrm{X}$ & $\mathrm{X}$ & $\mathrm{X}$ & $\mathrm{X}$ \\
\hline Ciclismo & - & $\mathrm{X}$ & $\mathrm{X}$ & $\mathrm{X}$ & $\mathrm{X}$ & $\mathrm{X}$ \\
\hline Futebol masculino & - & - & - & - & - & $\mathrm{X}$ \\
\hline Futsal masculino & - & $\mathrm{X}$ & $\mathrm{X}$ & $\mathrm{X}$ & $\mathrm{X}$ & $\mathrm{X}$ \\
\hline Futsal feminino & - & - & - & $\mathrm{X}$ & - & $\mathrm{X}$ \\
\hline $\begin{array}{ll}\text { Ginástica } & \text { Olímpica } \\
\text { masculino } & \end{array}$ & - & - & $\mathrm{X}$ & $\mathrm{X}$ & $\mathrm{X}$ & $\mathrm{X}$ \\
\hline $\begin{array}{l}\text { Ginástica } \quad \text { Olímpica } \\
\text { feminino }\end{array}$ & - & - & $\mathrm{X}$ & $X$ & $\mathrm{X}$ & $\mathrm{X}$ \\
\hline Ginástica Rítmica & - & - & $\mathrm{X}$ & $\mathrm{X}$ & $\mathrm{X}$ & $\mathrm{X}$ \\
\hline Handebol masculino & - & $\mathrm{X}$ & $\mathrm{X}$ & $\mathrm{X}$ & $\mathrm{X}$ & $\mathrm{X}$ \\
\hline Handebol feminino & - & $\mathrm{X}$ & $\mathrm{X}$ & $\mathrm{X}$ & $\mathrm{X}$ & $\mathrm{X}$ \\
\hline Judô masculino & - & $\mathrm{X}$ & $\mathrm{X}$ & $\mathrm{X}$ & $\mathrm{X}$ & $\mathrm{X}$ \\
\hline Judô feminino & - & - & - & $\mathrm{X}$ & $\mathrm{X}$ & $\mathrm{X}$ \\
\hline Caratê masculino & - & - & - & $\mathrm{X}$ & $\mathrm{X}$ & $\mathrm{X}$ \\
\hline Caratê feminino & - & - & - & $\mathrm{X}$ & $\mathrm{X}$ & $\mathrm{X}$ \\
\hline Natação masculino & $\mathrm{X}$ & $\mathrm{X}$ & $\mathrm{X}$ & $\mathrm{X}$ & $\mathrm{X}$ & $\mathrm{X}$ \\
\hline Natação feminino & $\mathrm{X}$ & $\mathrm{X}$ & $\mathrm{X}$ & $\mathrm{X}$ & $\mathrm{X}$ & $\mathrm{X}$ \\
\hline Punhobol & - & $\mathrm{X}$ & $\mathrm{X}$ & $\mathrm{X}$ & $\mathrm{X}$ & $\mathrm{X}$ \\
\hline
\end{tabular}




\begin{tabular}{|l|c|c|c|c|c|c|}
\hline $\begin{array}{l}\text { Saltos Ornamentais } \\
\text { masculino }\end{array}$ & $\mathrm{X}$ & $\mathrm{X}$ & $\mathrm{X}$ & $\mathrm{X}$ & - & - \\
\hline $\begin{array}{l}\text { Saltos Ornamentais } \\
\text { feminino }\end{array}$ & $\mathrm{X}$ & $\mathrm{X}$ & $\mathrm{X}$ & $\mathrm{X}$ & - & - \\
\hline Taekwondo masculino & - & - & - & - & - & $\mathrm{X}$ \\
\hline Taekwondo feminino & - & - & - & - & - & $\mathrm{X}$ \\
\hline $\begin{array}{l}\text { Tênis de Campo } \\
\text { masculino }\end{array}$ & $\mathrm{X}$ & $\mathrm{X}$ & $\mathrm{X}$ & $\mathrm{X}$ & $\mathrm{X}$ & $\mathrm{X}$ \\
\hline Tênis de Campo feminino & $\mathrm{X}$ & $\mathrm{X}$ & $\mathrm{X}$ & $\mathrm{X}$ & $\mathrm{X}$ & $\mathrm{X}$ \\
\hline Tênis de Mesa masculino & - & $\mathrm{X}$ & $\mathrm{X}$ & $\mathrm{X}$ & $\mathrm{X}$ & $\mathrm{X}$ \\
\hline Tênis de Mesa feminino & - & $\mathrm{X}$ & $\mathrm{X}$ & $\mathrm{X}$ & $\mathrm{X}$ & $\mathrm{X}$ \\
\hline $\begin{array}{l}\text { Tiro armas curtas/ } \\
\text { revolver }\end{array}$ & - & $\mathrm{X}$ & $\mathrm{X}$ & $\mathrm{X}$ & $\mathrm{X}$ & $\mathrm{X}$ \\
\hline $\begin{array}{l}\text { Tiro armas longas/ } \\
\text { carabina }\end{array}$ & - & $\mathrm{X}$ & $\mathrm{X}$ & $\mathrm{X}$ & $\mathrm{X}$ & $\mathrm{X}$ \\
\hline Tiro ao prato & - & $\mathrm{X}$ & $\mathrm{X}$ & $\mathrm{X}$ & $\mathrm{X}$ & $\mathrm{X}$ \\
\hline Tiro pombo & - & $\mathrm{X}$ & $\mathrm{X}$ & - & - & - \\
\hline Triathlon masculino & - & - & - & - & - & $\mathrm{X}$ \\
\hline Triathlon feminino & - & - & - & - & - & $\mathrm{X}$ \\
\hline Voleibol masculino & $\mathrm{X}$ & $\mathrm{X}$ & $\mathrm{X}$ & $\mathrm{X}$ & $\mathrm{X}$ & $\mathrm{X}$ \\
\hline Voleibol feminino & $\mathrm{X}$ & $\mathrm{X}$ & $\mathrm{X}$ & $\mathrm{X}$ & $\mathrm{X}$ & $\mathrm{X}$ \\
\hline $\begin{array}{l}\text { Vôlei de Duplas } \\
\text { masculino }\end{array}$ & - & - & - & - & - & $\mathrm{X}$ \\
\hline Vôlei de Duplas feminino & - & - & - & - & - & $\mathrm{X}$ \\
\hline Xadrez masculino & $\mathrm{X}$ & $\mathrm{X}$ & $\mathrm{X}$ & $\mathrm{X}$ & $\mathrm{X}$ & $\mathrm{X}$ \\
\hline Xadrez feminino & - & $\mathrm{X}$ & $\mathrm{X}$ & $\mathrm{X}$ & $\mathrm{X}$ & $\mathrm{X}$ \\
\hline Remo masculino & - & - & - & $\mathrm{X}$ & $\mathrm{X}$ & $\mathrm{X}$ \\
\hline Remo feminino & - & - & - & - & - & $\mathrm{X}$ \\
\hline No total de modalidades & $\mathbf{8}$ & $\mathbf{1 9}$ & $\mathbf{2 1}$ & $\mathbf{2 3}$ & $\mathbf{2 2}$ & $\mathbf{2 6}$ \\
\hline
\end{tabular}

Fonte: adaptado de FESPORTE (2014).

No quesito econômico, os JASC de 2012 movimentou aproximadamente 6 milhões de reais na economia local de Caçador, cidade sede do evento. Envolveram 7 mil pessoas entre atletas, dirigentes, árbitros e profissionais da organização do evento, número que representa $10 \%$ da população do município, que conta com quase 70 mil habitantes. Isso demonstra o impacto e o legado que um evento esportivo de grande porte, em nível regional, realiza na cidade sede do evento. São construídas e reformadas 
estruturas esportivas, como ginásios e quadras para comportar a competição (DIÁRIO CAÇADORENSE, 2013).

$\mathrm{Na} 53^{\mathrm{a}}$ edição realizada em Blumenau, é somada a participação de 177 municípios, incluindo as três etapas da competição; o que equivale a $60 \%$ do total de municípios do Estado. $\mathrm{Na}$ fase final, estimou-se a participação de cerca de 5 mil atletas (FESPORTE, 2013). Para a organização da competição, Blumenau recebeu do governo do Estado 1,5 milhões para investir na infraestrutura, logística e serviços dos JASC. Conforme o plano de ação (JORNAL DE SANTA CATARINA, 2013) desenvolvido pela FME os recursos foram destinados $42 \%$ para a infraestrutura das instalações esportivas, alojamentos e CCO; 45\% para os serviços; $11 \%$ para a logística relacionada a meios de transporte; e, 2\% para a alimentação.

Os eventos esportivos oportunizam o fortalecimento das identidades locais ao município sede (RAEDER, 2010). Durante as 53 edições os municípios de Brusque, Blumenau, Joaçaba e Chapecó sediaram cinco vezes o evento. Joinville foi o único que sediou quatro vezes. Enquanto, Florianópolis, Lages, Concórdia, Itajaí e Criciúma três vezes cada. Rio do Sul, Itajaí, São Bento do Sul, Tubarão, Caçador, Pomerode, Timbó, Indaial e Jaraguá do Sul duas vezes cada. Uma única vez, os municípios de Porto União, Herval do Oeste, Luzerna, Mafra, e Rio dos Cedros sediaram o evento. Assim, a região litorânea sediou mais vezes os JASC, atraindo maior investimento público em nível estadual e municipal, como indica a Figura 5 e o (QUADRO 3). O que vem ao encontro da região que detém a hegemonia e o maior número de títulos de campeão geral. Instituindo uma forma de territorialidade litorânea. 
Figura 5. Cidades que sediaram o JASC.

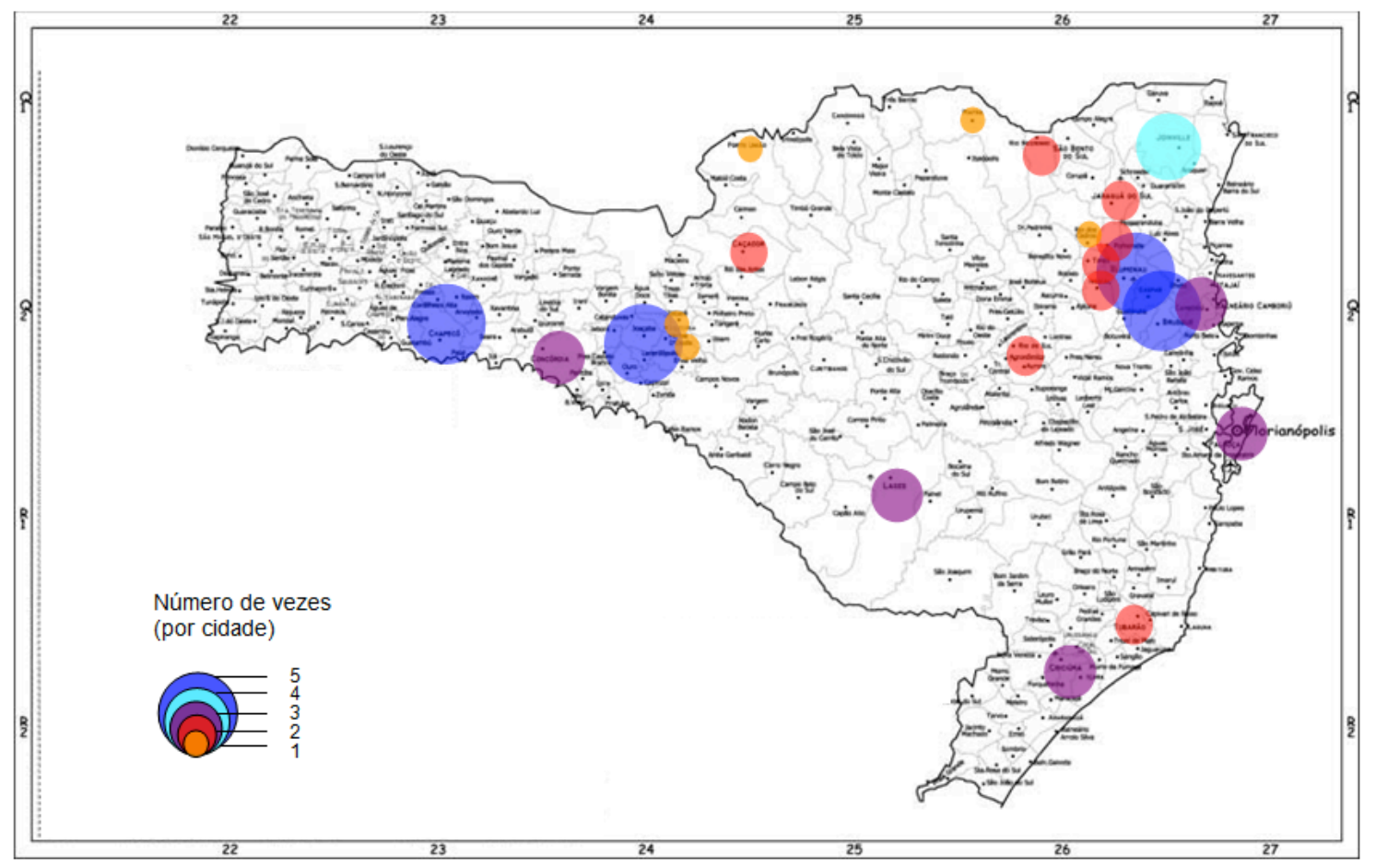

Fonte: adaptado de CASA DOS MAPAS, 2014.

Quadro

3. Ano, edição

e cidade

sede

$\operatorname{dos}$

JASC.

\begin{tabular}{|c|c|c|}
\hline Ano & Edição & Cidade Sede \\
\hline 1960 & $1^{\mathrm{a}}$ & Brusque \\
\hline 1961 & $2^{a}$ & Florianópolis \\
\hline 1962 & $3^{a}$ & Blumenau \\
\hline 1963 & $4^{a}$ & Joinville \\
\hline 1964 & $5^{a}$ & Porto União \\
\hline 1965 & $6^{\mathrm{a}}$ & Brusque \\
\hline 1966 & $7^{\mathrm{a}}$ & Lages \\
\hline 1967 & $8^{a}$ & Joaçaba \\
\hline 1968 & $9^{a}$ & Mafra \\
\hline 1969 & $10^{\mathrm{a}}$ & Joinville \\
\hline 1970 & $11^{\mathrm{a}}$ & Concórdia \\
\hline 1971 & $12^{\mathrm{a}}$ & Rio do Sul \\
\hline 1972 & $13^{\mathrm{a}}$ & Itajaí \\
\hline 1973 & $14^{\mathrm{a}}$ & São Bento do Sul \\
\hline 1974 & $15^{\mathrm{a}}$ & Criciúma \\
\hline 1975 & $16^{\mathrm{a}}$ & Chapecó \\
\hline 1976 & $17^{\mathrm{a}}$ & Tubarão \\
\hline
\end{tabular}

\begin{tabular}{|c|c|c|}
\hline $\mathbf{1 9 7 7}$ & $18^{\mathrm{a}}$ & Florianópolis \\
\hline $\mathbf{1 9 7 8}$ & $19^{\mathrm{a}}$ & Caçador \\
\hline $\mathbf{1 9 7 9}$ & $20^{\mathrm{a}}$ & Blumenau \\
\hline $\mathbf{1 9 8 0}$ & $21^{\mathrm{a}}$ & Jaraguá do Sul \\
\hline $\mathbf{1 9 8 1}$ & $22^{\mathrm{a}}$ & Lages \\
\hline $\mathbf{1 9 8 2}$ & $23^{\mathrm{a}}$ & Itajaí \\
\hline $\mathbf{1 9 8 3}$ & $*^{\mathrm{a}}$ & Não realizado* \\
\hline $\mathbf{1 9 8 4}$ & $24^{\mathrm{a}}$ & Concórdia \\
\hline $\mathbf{1 9 8 5}$ & $25^{\mathrm{a}}$ & Brusque \\
\hline $\mathbf{1 9 8 6}$ & $26^{\mathrm{a}}$ & Joinville \\
\hline $\mathbf{1 9 8 7}$ & $27^{\mathrm{a}}$ & Criciúma \\
\hline $\mathbf{1 9 8 8}$ & $28^{\mathrm{a}}$ & Joaçaba \\
\hline $\mathbf{1 9 8 9}$ & $29^{\mathrm{a}}$ & Joaçaba \\
\hline $\mathbf{1 9 9 0}$ & $30^{\mathrm{a}}$ & Blumenau \\
\hline $\mathbf{1 9 9 1}$ & $31^{\mathrm{a}}$ & Chapecó \\
\hline $\mathbf{1 9 9 2}$ & $32^{\mathrm{a}}$ & Joinville \\
\hline $\mathbf{1 9 9 3}$ & $33^{\mathrm{a}}$ & Tubarão \\
\hline $\mathbf{1 9 9 4}$ & $34^{\mathrm{a}}$ & Florianópolis \\
\hline & & \\
\hline
\end{tabular}




\begin{tabular}{|l|l|c|}
\hline $\mathbf{1 9 9 5}$ & $35^{\text {a }}$ & Rio do Sul \\
\hline $\mathbf{1 9 9 6}$ & $36^{\mathrm{a}}$ & São Bento do Sul \\
\hline $\mathbf{1 9 9 7}$ & $37^{\mathrm{a}}$ & Concórdia \\
\hline $\mathbf{1 9 9 8}$ & $38^{\mathrm{a}}$ & Joaçaba \\
\hline $\mathbf{1 9 9 9}$ & $39^{\mathrm{a}}$ & Chapecó \\
\hline $\mathbf{2 0 0 0}$ & $40^{\mathrm{a}}$ & Brusque \\
\hline $\mathbf{2 0 0 1}$ & $41^{\mathrm{a}}$ & Itajaí \\
\hline $\mathbf{2 0 0 2}$ & $42^{\mathrm{a}}$ & Lages \\
\hline $\mathbf{2 0 0 3}$ & $43^{\mathrm{a}}$ & Blumenau \\
\hline $\mathbf{2 0 0 4}$ & $44^{\mathrm{a}}$ & Pomerode, Indaial e Timbó \\
\hline $\mathbf{2 0 0 5}$ & $45^{\mathrm{a}}$ & Chapecó \\
\hline
\end{tabular}

\begin{tabular}{|c|c|c|}
\hline $\mathbf{2 0 0 6}$ & $46^{\mathrm{a}}$ & $\begin{array}{c}\text { Joaçaba, Herval d' Oeste e } \\
\text { Luzerna }\end{array}$ \\
\hline $\mathbf{2 0 0 7}$ & $47^{\mathrm{a}}$ & Jaraguá do Sul \\
\hline $\mathbf{2 0 0 8}$ & $48^{\mathrm{a}}$ & $\begin{array}{c}\text { Indaial, Pomerode, Rio } \\
\text { dos Cedros, Timbó } \\
\text { Cancelado* }\end{array}$ \\
\hline $\mathbf{2 0 0 9}$ & $49^{\mathrm{a}}$ & Chapecó \\
\hline $\mathbf{2 0 1 0}$ & $50^{\mathrm{a}}$ & Brusque \\
\hline $\mathbf{2 0 1 1}$ & $51^{\mathrm{a}}$ & Criciúma \\
\hline $\mathbf{2 0 1 2}$ & $52^{\mathrm{a}}$ & Caçador \\
\hline $\mathbf{2 0 1 3}$ & $53^{\mathrm{a}}$ & Blumenau \\
\hline
\end{tabular}

Fonte: adaptado de FESPORTE (2014).

A partir de 1969 , com a criação da premiação do título de campeão geral, as grandes cidades visualizam na competição uma forma de forte apelo político e vislumbram a conquista do título geral como veículo midiático. As cidades que anualmente figuram na disputa pela conquista do título geral dos jogos possuem o maior PIB $^{13}$ de Santa Catarina: Joinville, Florianópolis, Itajaí e Blumenau. Até o ano de 2013, Blumenau é o maior ganhador, soma quarenta títulos conquistados, enquanto Florianópolis possui oito e Joinville quatro (FIGURA 6). A conquista do título geral está relacionada a uma série de fatores. Visualizamos que essas cidades possuem projetos de iniciação esportiva, o que contribui para a continuidade do trabalho. Ainda, geralmente, possuem times que representam as FMEs e disputam competições nacionais por clubes e/ou associações que financiam atletas de alto nível. O que permite a captação de verbas do governo federal através de projetos de incentivo ao esporte. Outro fator está relacionado à importação de atletas de outros municípios para a disputa dos JASC.

\footnotetext{
${ }^{13}$ Segundo a Secretaria de Estado do Planejamento as cidades que tem o maior PIB em Santa Catarina são Joinville, Florianópolis, Itajaí e Blumenau. Dados disponíveis em: http://www.spg.sc.gov.br/dados_munic.php\#pibmunicipal .
} 
Figura 6. Mapa dos municípios campeões gerais.

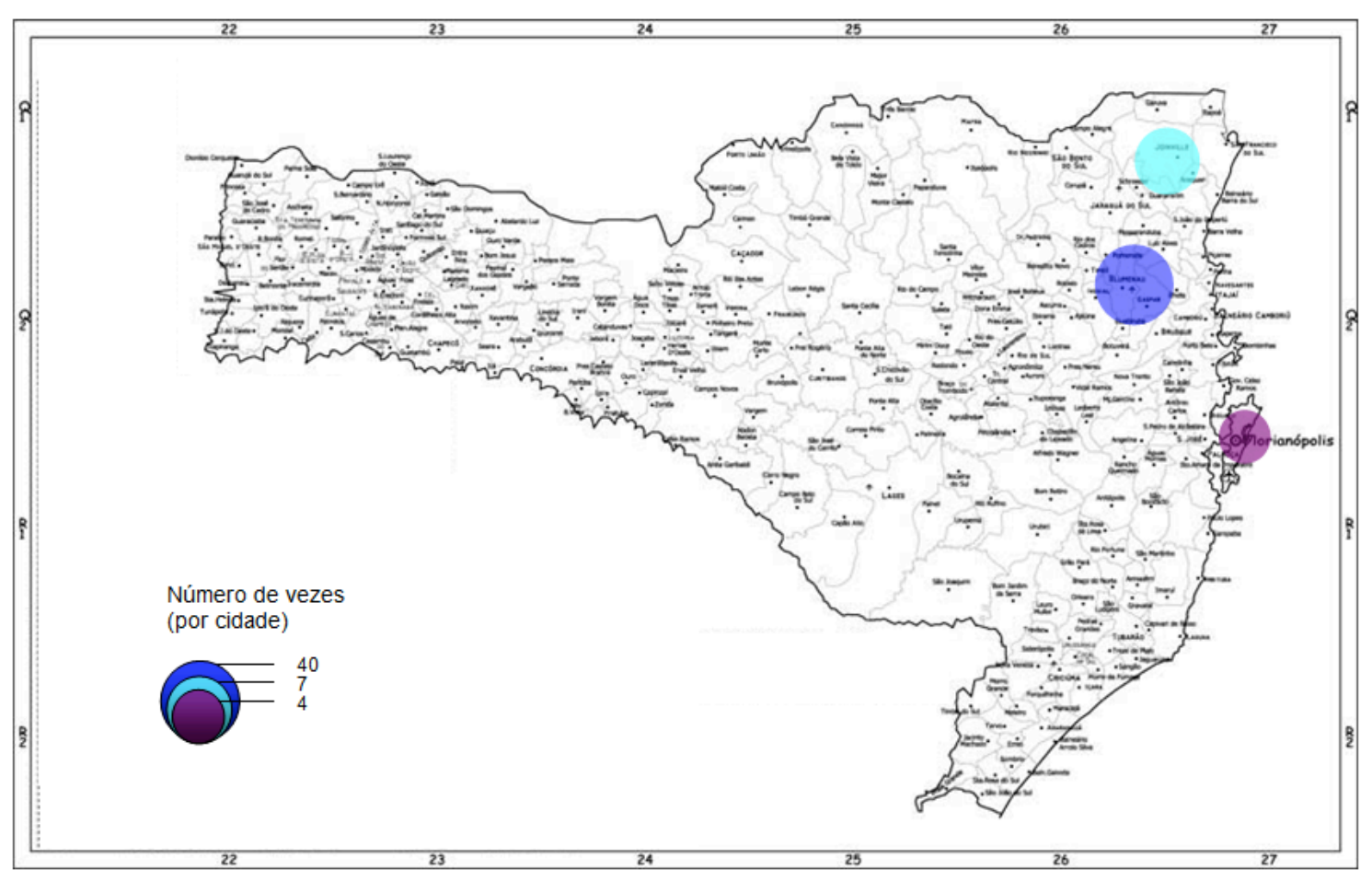

Fonte: adaptado de CASA DOS MAPAS, 2014.

Como observamos até o momento, há uma série de fatores e atores que envolvem a utilização do esporte e a realização de uma edição dos JASC. O que demonstra os fatores atrelados a aspectos econômicos, políticos, institucionais, técnicos, culturais, dentre outros. Elencamos adiante dez grupos de atores que interligados estabelecem associações que se mantém, sustentam e dissolvem em um contexto de reciprocidade composta pela interação de todos os envolvidos. Diversas associações instituem-se para a consolidação da competição, o que explicita diferentes atores são necessários para o desenvolvimento do evento.

Na Figura 7, a seguir, apresentamos os dez grupos de atores, a saber: (1) estado - representa o poder público como promotor do evento através da SOL e da FESPORTE; (2) fundações - municípios e sua delegação; (3) federações - material 
humano capacitado para gerir as modalidades específicas; (4) empresas - subsídio através dos materiais esportivos, premiação, alimentação; (5) modalidades esportivas compreendem os esportes disputados; (6) locais de competição - locais específicos para o desenvolvimento das modalidades; (7) infraestrutura - espaços necessários que extrapolam o ambiente propriamente esportivo; (8) mídia - visibilidade ao evento; (9) público alvo - interessados no evento; (10) patrocinadores - financiam e ao mesmo tempo promovem a competição.

Figura 7. Rede de atores humanos e não-humanos do JASC .

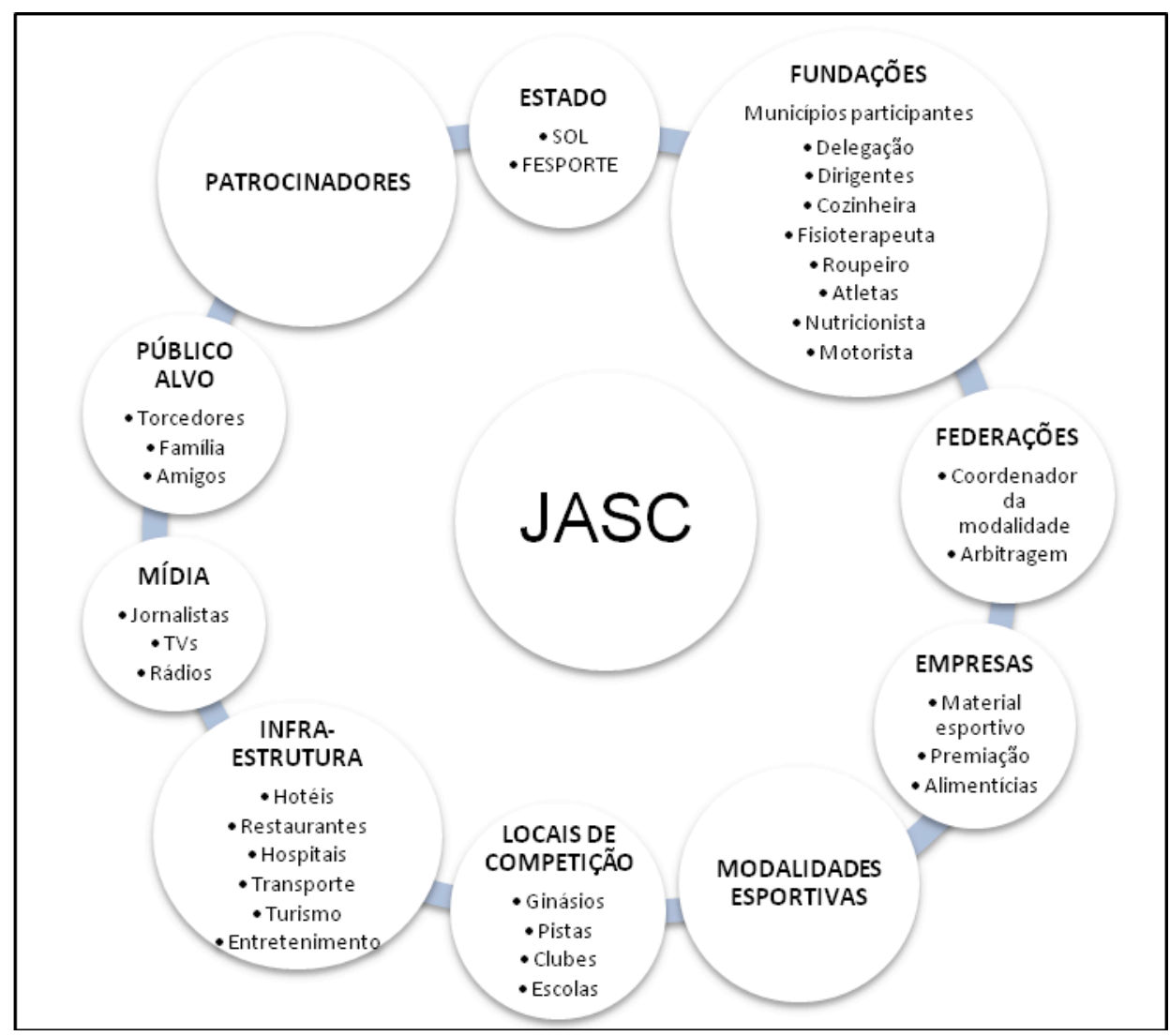

Fonte: elaborado pelos autores da pesquisa.

O desenvolvimento do esporte durante as 53 edições realizadas dos JASC causa algumas controvérsias. Inicialmente era utilizado como meio de sociabilidade e se torna ato político, com isso altera as relações sociais na produção do contexto social, sua 
estrutura se complexifica e o torna mais denso. Devido a sua estrutura, mesmo designado como um evento amadorístico, é reflexo do sistema profissional. Desse modo, mobiliza, alinha e opera conhecimentos e expertises de diversas áreas do conhecimento. Além de modificações na estrutura operacional, observa-se o crescimento do número de universidades, hoje cadastrados na plataforma e-MEC ${ }^{14}$ são vinte e nove instituições que oferecem curso de Educação Física presencial e, ainda, duas instituições apresentam curso à distância, totalizando setenta e oito cursos em atividade (que envolvem bacharelado e licenciatura). Fato que contribui para o aumento do nível técnico e a própria organização do evento. Considerando esse processo, os JASC é produto de um fenômeno social.

\section{Considerações Finais}

O esporte moderno está em constante transformação e no decorrer de sua institucionalização adquire diversas características. A disseminação e institucionalização do esporte no contexto catarinense tem relação com o processo de desenvolvimento e ocupação da região. No final do século XIX diversas foram as Sociedades de tradição germânica fundadas no estado de Santa Catarina. A fundação das Sociedades estava relacionada aos colonizadores europeus que se estabeleceram e constituíram redes sociais. A constituição dessas redes, por um lado, estava relacionada à manutenção das tradições próprias de cada cultura, sociabilidade e também indicava uma forma de controle social. Por outro, se estabelecia uma forma de educação por meio dos exercícios físicos que visavam à manutenção da saúde dos indivíduos e ao mesmo tempo do patriotismo. A forma de disseminação das Sociedades indica ainda

\footnotetext{
${ }^{14}$ Informação referente aos cursos de graduação em Educação Física em funcionamento foi retirado da plataforma e-MEC no dia 23 de agosto de 2014.
} 
que seu desenvolvimento esteve ligado à influência de diversos atores que prezavam por objetivos diferentes. Exemplo disso, visualizamos na ginástica idealizada por Jahn, sobretudo, o sentido patriótico.

A par dessa influência germânica, inicialmente, desenvolveram-se no estado de Santa Catarina aqueles esportes de tradição alemã, como o tiro e a ginástica. Após um período, as Sociedades aumentam o leque de esportes praticados e começa-se a criar as competições esportivas. Com o apoio das Sociedades que possuíam infraestrutura e material humano. Considerando isso, temos um período de transição no esporte catarinense. É criada uma competição de esporte amador - os JASC - que engloba diversas modalidades esportivas sendo disputadas ao mesmo tempo. A partir desse marco no âmbito esportivo, o esporte amador em Santa Catarina irá se (re)estruturar. Passa também a ser desenvolvido com o apoio do governo municipal por meio das FMEs.

Após esse caminhar que demarca a constituição da estrutura esportiva catarinense, é possível perceber que o esporte desenvolve-se em meio a várias facetas que acabam por demarcar também a sua forma de espacialização. Esse processo é mediado pelos atores que o desenvolvem e, por conseguinte, o influenciam. Cria-se a partir disso, regionalidades mediadas por esse processo estabelecido pelo esporte moderno, institucionalizado nas Sociedades de Ginástica e Sociedades de Tiro. Também, é por meio das competições esportivas promovidas pela FESPORTE, como os JASC. Concomitantemente, a fundação das federações, dos diversos esportes também subsidiam a espacialização do esporte amador no contexto catarinense. A constituição das regiões mais dinâmicas esportivamente indica que há uma diferenciação entre as localidades. No estado de Santa Catarina os municípios de Blumenau, Florianópolis e 
Joinville são os únicos ganhadores, até o ano de 2013, do título de campeão geral dos JASC. Isso expressa uma hierarquia entre os municípios do estado. Enquanto todos os municípios tem a possibilidade de conquistar o título de campeão geral, somente três o conquistaram.

\section{REFERÊNCIAS}

AFIF, A. A bola da vez: o marketing esportivo como estratégia de sucesso. São Paulo: Infinito, 2000.

BADO, T. N. Sociedade Esportiva Bandeirante: cem anos de história (1900-2000). Brusque: Mercúrio, 2000.

BANDEIRA, C. R.; RODRIGUES, H. M.; NAVARRO, A. C. Perfil dos técnicos de futsal feminino participantes dos Jogos Abertos do Interior em 2008 no Estado de São Paulo. Revista Brasileira de Futsal e Futebol, São Paulo, v.1, n.3, p.193-203. Set/Out/Nov/Dez. 2009.

BRASIL. Lei ${ }^{\circ}$ 9.615, de 24 de março de 1998. Institui normas gerais sobre desporto e dá outras providências. Disponível em: http://www.planalto.gov.br/ccivil_03/leis/19615consol.htm Acesso em: 22 jan. 2014.

COLETIVO DE AUTORES. Metodologia do Ensino de Educação Física. São Paulo: Cortez, 1993.

CASA DOS MAPAS. Mapa de Santa Catarina. Disponível em: $<$ http://www.casadosmapas.com.br/imagem/cartogramas/sc.jpg $>$. Acesso em: 10 maio 2014.

CORBIN, A. Historia dos tempos livres: o advento do lazer. Lisboa: Teorema, 2001.

COSTA, S. S. Santa Catarina: História, Geografia, Meio ambiente, Turismo e Atualidades. Florianópolis: Postix, 2011.

COSTA, L. P. Diagnóstico de Educação Física e desportos no Brasil. Rio de Janeiro: MEC, FENAME, 1971.

DIÁRIO CAÇADORENSE. Jasc injetam R\$ 6 milhões na economia local. Caçador. Disponível em: http://www.diariocacadorense.com/noticias-detalhes.php?id=3573 Acesso em: 10 dez. 2013.

FERREIRA, C.; ABREU, A. C. P. Os clubes de caça e tiro após a Segunda Guerra Mundial em Blumenau. Blumenau em cadernos, Blumenau, n. 11/12, p. 65 - 87, dez. 2005. 
FESPORTE. 53 JASC terá participação de atletas de 177 cidades. 2013. Disponível em: $<$ http://www.fesporte.sc.gov.br/index.php?option=com_content\&view=article\&id=1 544:53o-jasc-tera-participacao-de-atletas-de-177cidades \& catid=323:noticias\&Itemid=575>. Acesso em: 10 dez. 2013.

Jogos Abertos (JASC). 2014. Disponível em:

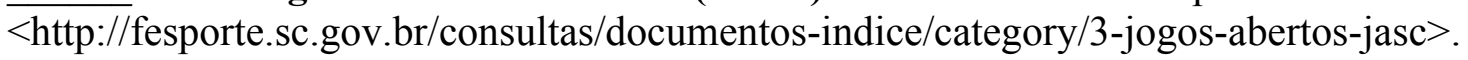
Acesso em: 20 fev. 2014.

Regulamento Geral Edição 2014. 2014b. Disponível em: <file://D:/Downloads/regulamento\%20geral\%20jasc\%20joguinhos\%20e\%20olesc\%20 atualizado.pdf $>$. Acesso em: Acesso em: 28 jun. 2014.

GOELLNER, S. V. et al. Garimpando memórias: esporte, Educação Física, lazer e dança no rio grande do sul. In: GOELLNER, S. V.; JAEGER, A. A. Garimpando memórias: esporte, educação física, lazer e dança. Porto Alegre: Editora da UFRGS, 2007. p. 39-49.

GOMES, M. A.; FRITSCHE, V. JASC 50 anos: história de vencedores. Florianópolis: ACAERT, 2010.

JENICHEN, O. Ipiranga 100 anos: 1893-1993. Florianópolis: Paralelo 27, 1993.

JOGOS Abertos de Santa Catarina. Para onde vai o dinheiro nos JASC. Jornal de Santa Catarina, Blumenau, 19 nov. 2013. Caderno de esportes. p. 12-15.

MAAR, A.; PERON, A.; DEL PRÁ NETTO, F. Santa Catarina: história, espaço geográfico e meio ambiente. 2. ed. rev. e ampl. Florianópolis: Insular, 2011.

MAZO, G. Z. Clubes e sociedades esportivas das cidades de Florianópolis, Blumenau e Joinville, SC. In: COSTA, L. (Org.). Atlas do Esporte no Brasil. Rio de Janeiro: SHAPE, 2005. p. 202-204.

MELO, V. A. Dicionário do esporte no Brasil: do século XIX ao início do século XX. Campinas: Autores Associados, 2007.

MEZZADRI, F. M. A estrutura esportiva no Estado do Paraná: da formação dos clubes as atuais políticas governamentais. 2000, $169 \mathrm{f}$. Tese (doutorado) - Universidade Estadual de Campinas, Faculdade de Educação Física, Campinas, 2000.

NOTÍCIAS de Vicente Só. Sociedade Amigos de Brusque - ontem e hoje. v. 9, n. 34, abr./jun. 1985.

NOTÍCIAS de Vicente Só. Sociedade Amigos de Brusque - ontem e hoje. n. 58. Blumenau: Nova Letra. jan./jul. 2012.

OLIVEIRA NETO, W. O tiro e as sociedades de atiradores em São Bento do Sul, Santa Catarina: aspectos históricos de um patrimônio cultural. 2010. Dissertação (Mestrado em Patrimônio Cultural e Sociedade) - Universidade da Região de Joinville, 2010. 
PARANÁ. Secretaria do Esporte e do Turismo do Estado do Paraná. Histórico: Jogos Abertos do Paraná - JAPs. 2014. Disponível em: http://www.jogosabertos.pr.gov.br/modules/conteudo/conteudo.php?conteudo $=48$ Acesso em: 9 jun. 2014.

PENAFORT, J. D. A integração do esporte adaptado com o esporte convencional a partir da inserção de provas adaptadas: um estudo de caso. Campinas, SP: [s. n.), 2001. Dissertação (Mestrado) - Universidade Estadual de Campinas, Faculdade de Educação Física.

PETRY, S. M. V. Os clubes de caça e tiro na região de Blumenau, 1859-1981. Blumenau: Fundação Casa Dr. Blumenau, 1982.

QUEIROZ, A. M. 25 anos de JASC (1960-1985): Joaçaba sempre presente. Joaçaba : [s.n.], 1990.

RAEDER, S. Jogos e cidades: ordenamento territorial urbano em grandes eventos esportivos. Brasília: Ministério do Esporte, 2010.

RUBIO, K. O imaginário esportivo contemporâneo: o atleta e o mito do herói. São Paulo: Casa do Psicólogo, 2001.

SANTA CATARINA. Lei n. ${ }^{\mathbf{9}} \mathbf{9 . 8 0 8}$, de 26 de dezembro de 1994. Publicada no Diário Oficial n. ${ }^{\circ}$ 15.088, de 26.12.94. Cria o Sistema Desportivo Estadual de Santa Catarina em consonância com o Art. 15 da Lei Federal n. ${ }^{\circ}$ 8.672, de 06 de julho de 1.993 e institui normas gerais sobre desportos e dá outras providências. Disponível em: $<$ http://www3.sol.sc.gov.br/fesporte/fesporte/leis_estadual/9808.htm $>$. Acesso em: 10 jul. 2013.

SÃO PAULO. Jogos Abertos do Interior. 2014. Disponível em: http://www.selt.sp.gov.br/jaihistorico.php . Acesso em: 20 julho 2014.

SEYFERTH, G. A colonização alemã no Vale do Itajai-Mirim: um estudo de desenvolvimento econômico. Porto Alegre: Movimento, 1974.

A idéia de cultura teuto-brasileira: literatura, identidade e os significados da etnicidade. Horizontes Antropológicos, Porto Alegre, n. 22, p. 149-197, jul./dez. 2004.

SOARES, C. L. Educação Física: raízes Européias e Brasil. Campinas: Autores Associados, 1994.

Da arte e da ciência de movimentar-se: primeiros momentos da ginástica no Brasil. In: DEL PRIORE, Mary; MELO, Victor Andrade de. História do esporte no Brasil: do Império aos dias atuais. São Paulo: Editora UNESP, 2009.

SOARES, D. Schutzenverein Sociedade de Atiradores. Florianópolis: Comissão Catarinense de Folclore: Biblioteca da Cultura Popular Catarinense, 1989.

SOCIEDADE GINÁSTICA DE JOINVILLE 1858-1958. Joinville: Sociedade Ginástica de Joinville, 1958. 
TRINDADE, H.; PEIXER, A. Deutscher sport: Tradition und siege. Nitro. Blumenau, 20 nov. 2013. p. 11-22.

VIEIRA, A. Jogos Abertos de Santa Catarina - 23 anos de influência no esporte amador estadual. Blumenau: [s.n.], 1983. 76p.

\section{Endereço dos Autores:}

Camila da Cunha Nunes

Max Hering, $\mathrm{n}^{\mathrm{o}} 285$, apto 505

Bairro: Victor Konder

Blumenau - SC - CEP: 89012-510

Endereço Eletrônico: camiladacunhanunes@gmail.com

Marcos Antônio Mattedi

Max Hering, $\mathrm{n}^{\circ}$ 55, apto 504

Bairro: Victor Konder

Blumenau - SC - CEP: 89012-510

Endereço Eletrônico: mam@furb.br 